No. 6(57), 2018, pp. 215-229

https://doi.org/10.12797/Politeja.15.2018.57.12

\author{
Vitaliy TERESHCHUK \\ Petro Mohyla Black Sea State University \\ vtereshchuk@ukr.net
}

\title{
POLITICAL AND INSTITUTIONAL \\ CHARACTERISTICS OF THE ENTRY \\ OF THE CEE REGION INTO REGIONAL \\ MEDIA SYSTEMS DURING THE BIPOLAR AND POST-BIPOLAR PERIODS
}

ABSTRACT In the newly shaped post-WWI Europe the CEE region was an integral part of the pan-European media system. The iron curtain that split Europe into two parts in the bipolar period, inevitably led to the emergence of two separate media systems, i.e. the Western European one and the one driven by the USSR (and existing predominantly in Eastern-European states). These systems were institutionalized by the establishment of separate broadcasting alliances and corresponding TV programme exchange networks. At the same time, in the context of the Cold War, the CEE region was a key target of Western broadcasting with the aim to counter Soviet propaganda and political influence. This factor reinforced by the willingness of the CEE countries to preserve their European identity caused the socialist media system (as well as other Soviet integration projects) to remain artificial and to be rejected in the region. It was clearly confirmed at the beginning of the post-bipolar period, when, after the collapse of the socialist camp and the USSR, the Soviet-driven International Radio and Television Organization ceased to exist, and the CEE countries integrated into the European Broadcasting Union, unleashing their desire to "return to Europe". At the same time, in the context of a policy aimed at preserving control over the post-Soviet space, Russia makes efforts which could be regarded as an attempt to restore (preserve) the common media space in the post-Soviet territories. In the paper the CEE region is regarded in the broadest way, including all states which were in socialist bloc, and appropriate former European Soviet republics. 
Keywords: Central and Eastern Europe, international broadcasting, Cold War, post-bipolar period, International Broadcasting Union, International Broadcasting Organization, International Radio and Television Organization, European Broadcasting Union.

\section{INTRODUCTION. FORMATION OF PAN-EUROPEAN MEDIA SYSTEM AND PLACE OF CEE IN IT}

The European media system is the oldest in the world, its origins can be found in the middle of the $19^{\text {th }}$ century, when the first international institutions were created. In particular, in 1865 twenty European countries established the International Telegraph Union (now the International Telecommunication Union) to coordinate common technological standards and protocols. Despite the non-participation of the British, whose telegraph networks were privately owned, this event has become an important milestone in the development of international information relations.

Understanding the peculiarities of the functioning of the CEE media space in the bipolar and the post-bipolar periods requires reference to the interwar period. In the 1920s, radio broadcasting became a new means of mass communication, however the League of Nations, in spite of its interest in broadcasting as a new mass media, nevertheless did not hasten to formulate international policy in the field of broadcasting.

The League showed an interest in broadcasting from the very first. As a result, it not only participated in international relay experiments, but also showed its belief that broadcasting could be used for diffusing its aims and ideology. The League was in touch with early European broadcasters and acquainted itself with their activities... Nonetheless, the League OCT ${ }^{1}$ did not take any concrete steps towards creating an international policy for broadcasting... [It was] decided not to create international broadcasting regulations as the technology was too "young" and changing too quickly. The decision left room for international efforts that were not driven by governments. ${ }^{2}$

Nevertheless, on April 22-23, 1924 in Geneva, a Preliminary Conference for an International Agreement on Wireless Telephony was held, with the participation of representatives of state administrations, private associations, radio industry. The conference agenda included, among other things, the first steps towards establishing a non-governmental institution. The idea of creating an international specialized non-governmental organization was also supported by the League of Nations. As a result both of these efforts and of negotiations with the BBC, the International Broadcasting Union (IBU), an alliance of European broadcasters, was established on April 10, 1925, by ten European Broadcasters (including one from the CEE region, namely from Czechoslovakia) with headquarters in Geneva. ${ }^{3}$

Organization for Communications and Transit

2 S.B. Lommers, Europe - on Air: Interwar Projects for Radio Broadcasting, Eindhoven 2012, p. 60.

3 See: Ibid., pp. 62-63. 
Because of the rapid development of broadcasting the IBU faced the need to address a very wide range of problems - from legal to socio-cultural. One of the key challenges was the nationalization of broadcasting companies in most European countries, which reflected the desire to strengthen control over these mass communication media in an interwar period. However, according to Sherman, in 1938 the IBU had 59 active and associate members, including US companies and organizations such as CBS, NBC, MBS and NAB. ${ }^{4}$ The CEE region was widely presented in the IBU by broadcasting organisations from Bulgaria (since 1938), Czechoslovakia (since 1925), Dantzig (since 1936), Estonia (since 1936), Hungary (since 1929), Latvia (since 1936), Lithuania (since 1936), Poland (since 1929), Romania (since 1929), Yugoslavia (since 1929, till 1936 as Kingdom of Serbia, Croatia and Slovenia). ${ }^{5}$

The events of World War II put an end to the functioning of the Union. The IBU equipment seized by Nazi Germany was used to monitor the broadcasting of the Allied Powers; the radio companies of the occupied countries went under the control of Germany or its collaborators. In such circumstances, 13 members withdrew from the IBU, and actually only the broadcasting organizations of the Axis powers and countries under their control remained in the Union. ${ }^{6}$ As for the CEE region, the following countries sent representatives to at least one or more annual meetings between 1941-44: Albania, Bohemia-Moravia, Bulgaria, Croatia, Hungary, Romania, and Slovakia. ${ }^{7}$ Such a situation undermined the credibility of the organization, raising the question of its future in the new conditions.

\section{COLD WAR}

The further course of events reflected the processes that took place in post-war Europe, namely the dividing of Europe and the beginning of the Cold War. In March 1946, an Information Meeting of European Broadcasting Organizations was convened in which 20 countries took part, including the Soviet Union. Despite the decision of the meeting to save the IBU, by reviewing its structure in accordance with new realities, the USSR demanded the dissolution of the International Broadcasting Union, and to create a new organization instead. Under its pressure, a relevant decision was made, and the new institution, the International Broadcasting Organization (OIR), was established on 28 June 1946 with 28 members, including the USSR, seven Soviet republics individually, as well as the CEE countries controlled by the USSR. Obviously, the existence of an organization with a clear domination of the Soviet Union, claiming the status of a pan-European one, and in the long run intended to become a world-wide institution,

\footnotetext{
Ch.E. Sherman, “Turmoil and Transition in International Broadcasting Organizations: 1938-1950", Journal of Broadcasting, vol. 15, no. 3 (1971), p. 266.

5 International Broadcasting Union, at <http://www.lonsea.de/pub/org/697>, 12 August 2018.

6 European Broadcasting Union, EBU 50th Anniversary, 2000, p. 12, at <https://www.ebu.ch/CMSimages/en/publications_50_e_tcm6-12446.pdf>, 12 August 2018.

$7 \quad$ Ch.E. Sherman, “Turmoil and Transition...", p. 272-273.
} 
did not suit the West European countries, and in November 1949, 11 broadcasting organizations, in particular, Belgium, France, Italy, the Netherlands, resigned from the OIR. ${ }^{8}$ This event marked the split of the European media system on the East European (communist) system controlled by the USSR and the Western European system. This split lasted up until the disappearance of the socialist camp and the Soviet Union itself.

The International Broadcasting Organization, which remained largely under the control of the USSR, moved to Prague in 1950, and in 1960 it changed its name to the International Radio and Television Organization (OIRT). In general, the active members of the OIRT during its existence were broadcasters of such countries (excluding those who left the organization before 1950): Afghanistan, Albania, Algeria, Belarus, Bulgaria, China, Cuba, Czechoslovakia, Estonia, Finland, the German Democratic Republic, Hungary, Latvia, Lebanon, Lithuania, Moldova, Nicaragua, North Korea, Poland, Romania, South Yemen, Ukraine, the USSR (Russia), and Vietnam; associate members - broadcasters of Mongolia and West Germany. The situation with membership in different periods reflects the foreign policy situation of that time. Thus, Albania and the People's Republic of China resigned their membership in the OIRT in 1961 after the Sino-Soviet split; Afghanistan became a member in 1978 after the revolution, which resulted in pro-Soviet forces coming to power; in 1950, Yugoslavia withdrew from the OIRT along with the Western European countries; Finland, by virtue of its specific status during the Cold War, was member of both the OIRT and the European Broadcasting Union (EBU).

The largest project implemented within the framework of the OIRT was the Intervision television network, the purpose of which was the exchange of television programmes and the preparation of programmes for dissemination in the participating countries, and the organization of international broadcasts. The decision to initiate it was taken in January 1960 at the meeting of the administrative council of the OIRT. The first participants were Czechoslovakia, the GDR, Hungary, and Poland; In subsequent years, Intervision was joined by other countries of the socialist camp, including the Soviet Union (since 1961). By the end of the 1980s, members of Intervision were broadcasters of Belarus, Bulgaria, Cuba, Czechoslovakia, Estonia, Finland, German Democratic Republic, Hungary, Latvia, Lithuania, Moldova, Mongolia, Poland, Romania, Ukraine, USSR, and Vietnam. The headquarters of Intervision was in Prague.

After the establishing of the Intervision network, programme exchange with Eurovision (the European Broadcasting Union network) began. It should be noted that throughout the Cold War the national broadcasting organizations within the Eurovision Network would always send more programmes to their counterparts in the Intervision Network than they would receive from them. Although the two sides agreed that the programme exchange should be mutual and voluntary, and that the programmes

See: Ibid., p. 268-271; European Broadcasting Union, EBU 50th Anniversary, p. 14.

“Интервидение”, in А.В. Кудрицкий (ed.), Украинский Советский Энциклопедический Словарь, vol. 1, Киев 1989, р. 693; Н.С. Бирюков, Буржуазное телевидение и его доктриньь, Москва 1977 , p. 239. 
involved should not politically attack the other side or be commercially motivated, the members of the Eurovision Network members considered many of the Intervision Network's proposals to be too politicized and uninteresting. The national broadcasting organizations individually decided which programmes they would choose from the other network's offer, and Intervision members also rejected programmes offered by the Eurovision Network that they deemed were commercial, political or religious. ${ }^{10}$

Being more of a political project than an alliance determined by the needs of the professional environment, Intervision during its existence was a kind of mirror of those socio-political processes that took place inside the socialist camp, an example of which is the Intervision song contest (ISC). The first successful attempts to hold it took place in the mid-1960s in Czechoslovakia. It's worth mentioning that this event could lead to normalization of relations between Eastern and Western Europe. In particular, in 1968 , following the liberalization of the political and, in particular, the cultural life of the country with the coming to power of Alexander Dubček, a competition was held in which representatives of not only the socialist countries, but also of the Western European countries - EBU members.

EBU national broadcasting organizations from Austria, Belgium, Finland, Spain, Switzerland, West Germany and Yugoslavia, together with OIRT ones from Bulgaria, Czechoslovakia, East Germany, Hungary, Romania, Poland and the USSR, were all represented in the 1968 ISC. The participation of Spain reflected Madrid's interest in developing diplomatic relations with Eastern Europe, while with West Germany it was a prelude to the normalization of relations with Eastern European states - with which Bonn mostly still did not have diplomatic relations in $1968 .{ }^{11}$

However, after suppression of the "Prague Spring", the project ceased to exist.

The "Polish period" of the ISC lasted between 1977 and 1980, and was suspended, probably, due to the imposition of martial law in Poland in $1981 .{ }^{12}$ Also, researchers note that the competition was subjected to heavy censorship, that the selection of participants was politically motivated, and that the launch of the contest in Poland had a propaganda goal, namely the desire to create a "socialist" alternative to the Eurovision Song Contest, to show the West that the socialist singers are not inferior to the Western. ${ }^{13}$

Also, the specific role of Finland, the only country whose public broadcaster Yleisradio (Yle) was member both of the EBU and the OIRT, including participation in both TV exchange networks - Eurovision (since 1959) and Intervision (since 1965). Like in foreign policy, Finland used broadcasting to position itself as a bridge builder between East and West. ${ }^{14}$

10 D. Vuletic, Postwar Europe and the Eurovision Song Contest, London 2018, p. 102.

11 Ibid., p. 106.

12 See: D. Vuletic, The Intervision Song Contest, 2017, p. 4, at <http://fiatifta.org/wp-content/uploads/2017/11/The-Intervision-Song-Contest-Dean-Vuletic.pdf>, 28 August 2018.

13 See: S. Rosenberg, The Cold War Rival to Eurovision. BBC News, 14 V 2012, at <https://www.bbc. com/news/magazine-18006446>, 29 August 2018.

14 See: M. Pajala, Intervision Song Contests and Finnish Television between East and West, at <https:// 
It is worth noting that, despite the rather distinct regional character of the socialist media system (based on the paradigm of confrontation between Western and Eastern Europe during the Cold War, it is entirely possible to consider it as an Eastern European one), if one takes into consideration the membership in the OIRT of Afghanistan, Cuba, Nicaragua, North Korea, South Yemen, and Vietnam, the Soviet-controlled media system can be considered as the only trans-regional system of its kind.

If we compare the role of the USA and the USSR as two poles in the bipolar world, we will note that their differences are of "mirror" character. The United States, as a non-European state, was excluded from the processes of functioning of the relevant structures of the West European media system, in particular, it was not an EBU member (although the USA, obviously, could have had some influence through its Western European partners), and as a result, its programmes did not circulate in the Eurovision network. But at the same time the American mass culture had significant influence on the European continent. Regarding the Soviet Union, it actively participated in the functioning of the OIRT (both directly and through the membership of individual republics), was one of the main suppliers of TV programmes for the Intervision, but the influence of Soviet culture outside the USSR was minimal.

The reason for the latter, in our opinion, was the desire of the CEE countries to preserve their European identity as one of the forms of resistance to the compulsory accession into the sphere of Soviet Union influence. Of course, the countries of the region historically considered themselves to be Europeans. However, as Curyło put it,

However, the political climate which, in many ways, subdued CEE for the most part of the 20th century severely undermined their capacity to construct policies that reflect their self-identification. Indeed, following WWII the CEE states found themselves in an ideological and military position which sharply contrasted to the post-war, emerging conceptualisation of "Western Europe." However, despite belonging to the new-found Communist political pole, the so-called "East," the CEE states did not entirely turn away from their "Europeanness," although such sentiment could not be explicitly demonstrated for fear of intervention by the USSR. ${ }^{15}$

The attempt to maintain a bond with Europe manifested itself, for example, in the fact that the organizers of the Intervision song contest in Poland invited western stars as guests, including the winners of the Eurovision Song Contest. This, according to the Polish music journalist Maria Szablowska, was "a window to a free world" for Polish citizens, an opportunity to feel free. ${ }^{16}$ This perfectly correlates with the general sentiment that prevailed in the societies of Soviet satellite countries. As an example, we can cite the Polish socio-political figure Adam Michnik: "What was Europe for people like me and my friends in Poland before 1989? Europe meant freedom, normalcy, econom-

www.academia.edu/5775175/Intervision_Song_Contests_and_Finnish_Television_between_East_ and_West>, 29 August 2018.

15 B. Curyło, "BarBarians at the Gate... The Ideas of Europe in CEE", Central European Journal of International and Security Studies vol. 5, no. 1 (2011), p. 136.

16 S. Rosenberg, The Cold War Rival... 
ic rationality. Europe was the West, to, to which we naturally belonged, even if we were forcibly expelled from it by Soviet dictates. Europe was a light on the western horizon, a hope that our country, too, might one day become free". ${ }^{17}$

After the collapse of the socialist camp and the USSR, the reason for existence of a separate Eastern European institution, along with the successful EBU, has disappeared. Although there were initiatives to merge the EBU and the OIRT, ${ }^{18}$ they had no prospects. As a result, on October 22, 1992, at an extraordinary session of the OIRT, a decision was made to dissolve the organization from December 31, with subsequent inclusion of its members in the European Broadcasting Union. ${ }^{19}$ In 2014, Russia proclaimed ambitious initiative to revive the Intervision song contest as an alternative to the Eurovision Song Contest, which was expected to be attended by participants from the member states of the Commonwealth of Independent States and of the Shanghai Cooperation Organization, as well as from Baltic States, South Korea, and Japan. ${ }^{20}$ However, this initiative was not successful.

\section{THE CEE REGION AS AN ARENA OF INFORMATION CONFRONTATION BETWEEN THE USSR AND THE UNITED STATES}

The propaganda impact on the Soviet Union and the countries of Central and Eastern Europe, as well as the use of radio broadcasting technical capabilities, played an important part in US foreign policy. So, on April 20, 1950, US President Harry Truman appealed to the American Society of Newspaper Editors in a speech called "Campaign of Truth", which included the following key points:

The cause of freedom is being challenged throughout the world today by the forces of imperialistic communism. This is a struggle, above all else, for the minds of men. Propaganda is one of the most powerful weapons the Communists have in this struggle. Deceit, distortion, and lies are systematically used by them as a matter of deliberate policy... We must make ourselves known as we really are - not as Communist propaganda pictures us. We must pool our efforts with those of other free peoples in a sustained, intensified program to promote the cause of freedom against the propaganda of slavery. We must make ourselves heard round the world in a great campaign of truth. ${ }^{21}$

17 A. Michnik, "What Europe Means for Poland”, Journal of Democracy vol. 14, no. 4 (2003), p. 128.

18 Seе: В. Аазуткин, “Вспоминая Интервидение”, Broadcasting. Телевидение и радиовещание, 3 (2017), at <http://broadcasting.ru/articles2/Mashina/vspominaya-intervidenie/>, 18 August 2018.

19 “«Интервидение» входит в «Евровидение»: «Интервидения» больше нет. А его должники есть", Коммерсантъ, 22 X 1992, at <https://www.kommersant.ru/doc/27421>, 18 August 2018.

20 “Россия нашла замену «Евровидению»”, Dni.ru, 21 V 2014, at <https://dni.ru/showbiz/2014/ 5/21/270892.html>, 18 August 2018.

21 H.S. Truman, Address on Foreign Policy at a Luncheon of the American Society of Newspaper Editors, April 20, 1950, at <https://www.trumanlibrary.org/publicpapers/index.php?pid=715>, 18 August 2018. 
In the early 1960s, President Kennedy sought to build up Voice of America broadcasting for the "peaceful evolution" of socialist countries. The President aimed to make the broadcasts "leap national borders and the oceans, the 'Iron Curtain' and stone walls, in a life-and-death competition with communism." A U.S. Congress report then noted, "Radio broadcasting is a most valuable means of promoting foreign policy... We need to re-acknowledge the strategic role of broadcast stations, considering our strategic superiority, to conscientiously reappraise radio broadcasting... Radio broadcasting is the only way to overthrow socialism."22

One of the main instruments of propaganda influence on the USSR and the socialist block was the American Voice of America (VOA), Radio Free Europe (RFE) and Radio Liberty (RL). VOA radio service was established in early 1942 to carry out radio propaganda against Nazi Germany and its allies. After World War II, the service was subordinated to the US Department of State. On February 17, 1947, radio broadcasting to the Soviet Union was started. And on April 24, 1949, the USSR began the jamming of VOA programs. Subsequently, the service was included as an element of the United States foreign policy strategy to combat Soviet propaganda.

The other two US radio services created in the late 1940s by the US Central Intelligence Agency were Radio Free Europe and Radio Liberation. The former was broadcast to Eastern Europe, whereas the latter to the Soviet Union. As Dizard noted,

The decision to create the two Radios stemmed partly from criticisms by Cold War hard-liners in Washington that the Voice of America was net aggressive enough in attacking the Soviet Union. Although the VOA had at times shifted from its original mandate of presenting a "full and fair" picture of the United States to include mere direct criticism of Soviet policies and actions, the change did not satisfy the hard-liners. They saw the RFE/ $R L$ stations as surrogate voices within the Soviet bloc providing listeners with information denied them by their own governments. ${ }^{23}$

For a long time, Radio Free Europe and Radio Liberation concealed the fact that they were funded by the US intelligence service, the CIA, and they were presented as a private American propaganda network. Edward Bernays, one of the leading people in the history of US propaganda, gave very frank explanations about the reasons for this:

First, it is undoubtedly true that a private agency in foreign countries does not suffer from its being stamped as a governmental propaganda agency. In that way it may possibly develop greater credibility for what it disseminates. Second, a private agency has somewhat more flexibility in discussing affairs because it is not bound by whatever limitation any government is bound to have as to what it can and cannot say. Third, it is not subject to possible political pressures of one sort or another that are bound to encumber any organization that is dependent upon yearly appropriations made by the national legislature. ${ }^{24}$

22 Cit. ex: M. Price, “The Transformation of International Broadcasting”, Cardozo Arts and Entertainment Law Journal vol. 21, no. 1 (2003), p. 55, at <https://repository.upenn.edu/cgi/viewcontent. cgi ?article $=1120 \&$ context $=$ asc_papers $>, 18$ August 2018 .

23 W.P. Dizard, Inventing Public Diplomacy: The Story of the U.S. Information Agency, London 2004, p. 142.

24 Cit. ex: R.T. Holt, Radio Free Europe, Minneapolis 1958, p. 200. 
In 1959, Radio Liberation changed its name to Radio Liberty, and in 1976, both radio services were united into a single radio service Radio Free Europe/Radio Liberty (RFE/RL). The audience of the American "voices" was quite significant: the number of listeners reached half the population of the USSR and 70-80\% of the population of Eastern Europe during the Cold War. ${ }^{25}$ The Soviet leadership tried to resist to Western broadcasting by jamming which was in general ineffective, and by producing radio receivers with a limited frequency range (apparently, those frequencies were subducted on which the "enemy voices" were broadcasting). The CEE region was also partly included in the scope of the USSR's jamming efforts. Thus, on 20 August 1980 Soviet jamming activities were extended to Poland during a crisis caused by the emergence of the Solidarity trade union, and Czechoslovakia and Bulgaria were also aided in their jamming activities against RFE/RL. ${ }^{26}$

However, like it was in political sphere, the socialist bloc of the CEE countries was not monolithic, and some countries allowed unhindered Western broadcasting on their territories. For example, "Romania ceased jamming of RFE in 1963 because of its decision to establish an independent foreign policy. The cessation of jamming was a means by which Romanian officials could communicate to the West that it was moving towards independence, no longer feared outside ideas, and deserved help." ${ }^{27}$

There were also other international broadcasters which took part in the battle for the hearts and minds of the CEE audiences, including the BBC World Service, Deutsche Welle, etc. Although they claimed that they were only information broadcasters, and not propaganda tools, they were fully aware of their role as an opponent of the USSR and of the puppet governments supported by it in the satellite states. This is indirectly confirmed by the fact that, after the end of the Cold War, much of the CEE-oriented broadcasting services were curtailed. For example, in the post-bipolar period the BBC World Service closed most of its language services targeted at CEE, namely Yugoslav (in 1991), Bulgarian, Polish, Slovak, Slovenian, and Hungarian (in 2005), Croatian and Czech (in 2006), Romanian (in 2008) $;{ }^{28}$ in 2004-2005 the Voice of America discontinued broadcasting in Bulgarian, Czech, Estonian, Hungarian,

25 See: J.S. Nye, "Public Diplomacy and Soft Power", The ANNALS of the American Academy of Political and Social Science, vol. 616 (2008), p. 98.

26 J. Eyal, "The Jamming of Western Radio Broadcasts to Eastern Europe and the Soviet Union: The CSCE Compromise and its Future", Radio Liberty Research (1989), at <http://www.icnl.org/research/resources/digital_freedoms/324d582c-c345-4260-9c60-8f5b6fd1f3f0_l.pdf>, 17 August 2018.

27 Cold War Broadcasting Impact. Report on a Conference organized by the Hoover Institution and the Cold War International History Project of the Woodrow Wilson International Center for Scholars at Stanford University, October 13-16, 2004, p. 30, at <http://media.hoover.org/sites/default/files/ documents/broadcast_conf_rpt.pdf $>, 18$ August 2018.

28 "World Service Language Timeline", BBC World Service, 8 II 2007, at <http://www.bbc.co.uk/ worldservice/history/story/2007/02/070208_html_multilingual_audio.shtml>, 18 August 2018; "BBC shuts down Romanian service", $B B C \bar{N} E W \bar{S}, 25$ VI 2008, at <http://news.bbc.co.uk/2/hi/ europe/7473778.stm>. 
Latvian, Lithuanian, Polish, Romanian, Slovak, and Slovene, which lasted uninterruptedly since the $1940 s-1950$ s. $^{29}$

\section{THE POST-BIPOLAR PERIOD}

As it was mentioned above, all CEE countries joined the European Broadcasting Union, which can be seen as the reunification of a pan-European media system. Thus, the CEE region has ceased to be part of a separate involuntary media system. However, after the collapse of the Soviet Union, some activity on the part of Russia could be regarded as an attempt to restore (preserve) the common media space in the post-Soviet territories.

Thus, on October 9, 1992, in Bishkek, representatives of several members of the Commonwealth of Independent States, namely Armenia, Belarus, Kazakhstan, Kyrgyzstan, Moldova, Russia, Tajikistan and Uzbekistan signed an Agreement on the Establishment of an Interstate Television and Radio Company (Mezhgosudarstvennaya teleradiokompaniya, hereinafter MTRK). The preamble to the document indicated the commitment of the participating states to the universal principles of international exchange of information, the belief in the need to more effectively meet the growing desire of the people of the Commonwealth to know and understand each other and, and to cooperate in television and radio broadcasts for the sake of common interests and on the basis of equality and mutual respect. ${ }^{30}$

The Statute of the MTRK, approved on January 22, 1993, states that :

The main purpose of the Company's activity is to provide a more complete and high-quality satisfaction of the needs of citizens of the founding member states in [terms of] comprehensive [and] objective information about the events and processes taking place in the founding states and on the world stage, as well as to meet their cultural needs by means of television and radio broadcasting. ${ }^{31}$

The activities of the MTRK include, in particular:

production and distribution of television and radio programs in the territories of the founding states; access to the global information space, taking into account the national features and specific interests of the founding states in strict compliance with the obligations of signatory states in international treaties; promoting participation in the global information space of the national state television and radio organizations of the founding states; allocation of airtime for official information provided by the representatives authorized by the founding states. ${ }^{32}$

29 VOA Languages, 18 XII 2017, at <https://docs.voanews.eu/en-US-INSIDE/2017/12/18/ b83d4884-66a1-41eb-8fe0-31bc3bc0c465.pdf>, 19 August 2018.

30 Соглашение о создании Межгосударственной телерадиокомпании (9 октября 1992 г.), at <http:// cis.minsk.by/reestr/ru/index.html\# reestr/view/text?doc=155> 20 August 2018.

31 Решение о вопросах Межгосударственной телерадиокомпании (22 января 1993 г.), at <http://cis. minsk.by/reestr/ru/index.html\#reestr/view/text?doc=181>, 20 August 2018 (translation mine).

32 Ibid. 
Subsequently, on December 24, 1993, the Agreement on the International Legal Guarantees of Unhindered and Independent Implementation of the Inter-State Television and Radio Company "Mir" was signed. There is already an indication in the preamble to this document of the aspiration of the participating states to create a common information space of interested states. ${ }^{33}$ The agreement was signed by 10 countries: in addition to the 8 mentioned above, they were Azerbaijan and Georgia.

Within the framework of the MTRK, TV channels Mir, Mir 24, Mir Premium, radio station Mir, and analytical web-portal MIR24.TV were created. One more area of cooperation within the framework of the MTRK was the formation of an information pool in March 2008. The purpose of its creation was to restore TV programme exchange within the post-Soviet space. The participants of the pool were 9 states, including Ukraine (TV Channel Inter), but in 2018, the information about Ukraine's (as well as of Moldova's) participation in the pool disappeared from MTRK website.

Particular attention in the context of Russia's efforts to preserve its control over the former common information space should be paid to the Council of CIS Heads of Governments' approval on October 18, 1996 of the Conception of formation of the information space of the Commonwealth of Independent States. According to the concept:

The main purpose of the work on the formation of the information space of the CIS member states is to ensure the interaction of national information spaces of the Commonwealth countries on a mutually beneficial basis, taking into account national and common interests in the development of cooperation in the agreed fields of activity. ${ }^{34}$

Among the common interests of the CIS countries mentioned in the concept are the ensuring of information security, the development of education, science, technology and culture, and providing access to national and international information resources. ${ }^{35}$

However, despite this formulation, the real purpose behind the formation of the information space of the CIS was to preserve Russias domination in the post-Soviet space. The paper by Ivan Surma, Professor of the Diplomatic Academy of the Ministry of Foreign Affairs of the Russian Federation, which is devoted to the reasons for the failure of forming an integrated CIS information space, is rather indicative in this regard..$^{36}$ Among those reasons, the author includes the prevalence of centrifugal tendencies over centripetal ones among the Commonwealth member states; the presence of sharp contradictions between individual participating states; counteraction on the

33 Соглашение о международно-правовых гарантиях беспрепятотвенного и независимого осуществления деятельности Межгосударственной телерадиокомпании «Мир» (24 декабря 1993 г.), at $<$ http://cis.minsk.by/reestr/ru/index.html\#reestr/view/text?doc=282>, 20 August 2018 (translation mine)

34 Конщепиия формирования информационного пространства Содружества Независимьх Государств (18 октября 1996 г.), at <http://cis.minsk.by/reestr/ru/index.html\# reestr/view/text? doc $=643>, 20$ August 2018 (translation mine).

35 Ibid.

36 Seе: И.В. Сурма, “Единое информационное пространство СНГ: 20 мет спустя”, Bопросы безопасности, 5 (2015). 
part of the West against any integration processes on the territory of the former USSR; the strengthening of regional centres of power (Turkey, China, India, Iraq) and their information expansion in the CIS; protectionist measures taken by some CIS member states aimed to create and protect their own information space, their desire for implementing independent national information policy, etc. In his paper, the author explicitly acknowledges that "the Russian language is a system-forming and integrating factor in solving the problem of creating an integrated information field in the CIS", and "the role of the Russian language and Russian culture in shaping the mindsets and integration advantages in the information space of the CIS" is decisive. Interestingly, at the same time, the author appeals to the experience of "friendly interaction and interpenetration of national cultures of the former Soviet republics," although in its analysis he completely ignores the interactions and influence of the CIS member states among themselves. In addition, according to the author, the broadcast of such a frank propaganda tool as the TV channel $R T$ could be "a constructive solution to the issue of informational influence on 'unfriendly partners' in the CIS (in Ukraine, Moldova) and other former Soviet republics in which Russophobia almost became the official state policy (in Lithuania, Latvia, Estonia)." In point of fact, the author admits that the attempt to create an integrated CIS information space should serve to preserve and strengthen the political and informational unity in the former Soviet Union under Russia's leadership; that Russia is trying to pursue a policy of limited information sovereignty of the other CIS member states, in which any attempt by them to implement an independent information policy, in particular, oriented towards integration with the West and restricting the use of the Russian language in favour of the national one, is considered to be unfriendly and even hostile.

This gives us grounds for characterizing this media system as a trans-border Russian media system, rather than post-Soviet, Eurasian or the like. Proceeding from this, as well as from the recent trends, it is difficult to talk about the current and future outlines of this system. And here it is necessary to differentiate the actual Russian trans-border media system, which is based on the desire to preserve and strengthen the integrated information space controlled by Russia, and Russia’s practice in recent years of active dissemination of propaganda through various media channels in foreign countries. In our opinion, the possibility of preserving this media system within the CIS boundaries is hardly probable, given that the influence of Russian culture in the post-Soviet countries of Central Asia and the Caucasus, as well as Moldova, is steadily decreasing, and they will be more likely to become closer (also in terms of the media sphere) to their more culturally similar neighbours - for example, Moldova to Romania, Azerbaijan to Turkey, etc. As a result, even with the preservation of formal signs of cooperation in the media sphere, there is no longer any reason to talk about the real existence of an integrated post-Soviet space controlled by Russia. As for the two countries in which the influence of Russian culture and media products is more deeply rooted, namely Ukraine and Belarus, the former has been actively engaged in limiting this influence in recent years, although, in our opinion, there's no reason to think that it will disappear or become insignificant in the short, or even medium, 
term. Therefore, the coverage of the trans-border Russian media system, apart from

the Russian Federation itself, will be limited to Belarus and the occupied territories of Ukraine, Georgia and Moldova.

As we mentioned above, the CEE region largely ceased to be the focus of attention of major international broadcasters. The only exception may be Ukraine, with its language services of the VOA (since 1949), the BBC World Service (since 1992), and DW (since 2000).

\section{CONCLUSIONS}

Summing up the political and institutional characteristics of the entry of the CEE region into the regional media systems during the bipolar and post-bipolar periods, we can assert that (a) Before the outbreak of WWII the CEE region was an integral part of the pan-European media system, despite the fact that most countries of the region regained their statehood after the end of the WWI. (b) The compulsory division of Europe into two opposing camps during the Cold War resulted in a split of the European media system into two, i.e. the Western European one and the one driven by the USSR (including mostly Eastern-European states). This split was institutionalized by the establishment of separate broadcasting alliances (the EBU and the OIRT) and corresponding TV programme exchange networks (namely Eurovision and Intervision), and although these networks interacted, the exchange of programmes was not balanced and was conditioned, among other things, by propagandist and ideological considerations. The existence of special "socialist" institutions can be considered in the context of the conventional practice on the part of the USSR of establishing special organizations (like the Warsaw Pact military alliance, the Council for Mutual Economic Assistance, etc.) aimed at the strengthening of Soviet control over the satellite states and at manifesting "the unity" of the socialist bloc. (c) The Central and Eastern European region also was targeted by heavy Western broadcasting, both Western-European and American. This broadcasting was used in two ways, as a propaganda tool and as a means to disseminate information, but the latter can be clearly regarded as a kind of propaganda (or counter-propaganda) as well, in the context of the socialist media space, filled with false, biased and distorted information. Western broadcasting was reasonably treated by the USSR as a threat to Soviet domination in the region and was countered primarily by means of jamming. Nevertheless, some of the CEE states allowed unhindered Western broadcasting on their territories, manifesting at least apparent independence from the Soviet Union. (d) The CEE countries tried to preserve their "Europeanness", including keeping bonds with the Western European media system, accepting Western cultural products instead of Soviet ones, and paying great attention to Western broadcasting. (e) The beginning of the post-bipolar period was marked primarily by the collapse of the artificial Eastern European media system and its integration into the Western European media system. At the same time, Russia demonstrated efforts to preserve its domination in the post-Soviet media space (both directly and through the CIS). 
However, these efforts, in our opinion, have no long-term prospects. Also, the CEE region mostly disappeared from focus of attention of major international broadcasters. As a result, nowadays this region has no special distinctive features and tries to be an inseparable part of the pan-European media system.

\section{BIBLIOGRAPHY}

"BBC shuts down Romanian service", BBC NEWS, 25 VI 2008, at <http://news.bbc.co.uk/2/ hi/europe/7473778.stm>.

Cold War Broadcasting Impact. Report on a Conference organized by the Hoover Institution and the Cold War International History Project of the Woodrow Wilson International Center for Scholars at Stanford University, October 13-16, 2004, at <http://media.hoover. org/sites/default/files/documents/broadcast_conf_rpt.pdf $>$.

Curyło B., "BarBarians at the Gate... The Ideas of Europe in CEE", Central European Journal of International and Security Studies vol. 5, no. 1 (2011).

Dizard W.P., Inventing Public Diplomacy: The Story of the U.S. Information Agency, London 2004.

European Broadcasting Union, EBU 50th Anniversary, 2000, at <https://www.ebu.ch/CMSimages/en/publications_50_e_tcm6-12446.pdf>.

Eyal J., "The Jamming of Western Radio Broadcasts to Eastern Europe and the Soviet Union: The CSCE Compromise and its Future", Radio Liberty Research (1989), at <http://www. icnl.org/research/resources/digital_freedoms/324d582c-c345-4260-9c60-8f5b6fd1f3f0 ll.pdf>.

Holt R.T., Radio Free Europe, Minneapolis 1958.

International Broadcasting Union, at <http://www.lonsea.de/pub/org/697>.

Lommers S.B., Europe - on Air: Interwar Projects for Radio Broadcasting, Eindhoven 2012, https://www.doi.org/10.6100/IR734076.

Michnik A., "What Europe Means for Poland", Journal of Democracy vol. 14, no. 4 (2003), https://www.doi.org/10.1353/jod.2003.0083.

Nye J.S., "Public Diplomacy and Soft Power", The ANNALS of the American Academy of Political and Social Science, 616 (2008), https://www.doi.org/10.1177/0002716207311699.

Pajala M., Intervision Song Contests and Finnish Television between East and West, at $<$ https:// www.academia.edu/5775175/Intervision_Song_Contests_and_Finnish_Television_between_East_and_West $>$.

Price M., "Public Diplomacy and the Transformation of International Broadcasting", Cardozo Arts and Entertainment Law Journal vol. 21, no. 1 (2003), at <https://repository.upenn. $\mathrm{edu} / \mathrm{cgi} / \mathrm{viewcontent.cgi}$ ?article $=1120 \&$ context $=$ asc_papers $>$.

Rosenberg S., "The Cold War Rival to Eurovision”, BBC News, 14 V 2012, at <https://www. bbc.com/news/magazine-18006446>.

Sherman Ch.E., "Turmoil and Transition in International Broadcasting Organizations: 1938-1950", Journal of Broadcasting vol. 15, no. 3 (1971), https://www.doi.org/10.1080/ 08838157109363645 . 
Truman H.S., Address on Foreign Policy at a Luncheon of the American Society of Newspaper Editors, April 20, 1950, at <https://www.trumanlibrary.org/publicpapers/index. php?pid $=715>$.

VOA Languages, 18 XII 2017, at <https://docs.voanews.eu/en-US-INSIDE/2017/12/18/ b83d4884-66a1-41eb-8fe0-31bc3bc0c465.pdf>.

Vuletic D., Postwar Europe and the Eurovision Song Contest, London 2018.

- The Intervision Song Contest, 2017, at <http://fiatifta.org/wp-content/uploads/2017/11/ The-Intervision-Song-Contest-Dean-Vuletic.pdf $>$.

“World Service language timeline”, BBC World Service, 8 II 2007, at <http://www.bbc.co.uk/ worldservice/history/story/2007/02/070208_html_multilingual_audio.shtml>.

Бирюков Н.С., Буржуазное телевидение и его доктриньь, Москва 1977.

“Интервидение”, in А.В. Кудрицкий (ed.), Украинский Советский Энщиклопедический Словарь, vol. 1, Киев 1989.

“«Интервидение» входит в «Евровидение»: «Интервидения» больше нет. А его Аолжники есть”, Коммерсантъ, 22 X 1992, at <https://www.kommersant.ru/doc/27421>.

Конщепция формирования информационного пространства Содружества Независимьх Государств (18 октября 1996 г.), at <http://cis.minsk.by/reestr/ru/index.html\#reestr/ view $/$ text ?doc $=643>$.

Мазуткин В., “Вспоминая Интервидение”, Broadcasting. Телевидение и радиовещание, 3 (2017), at <http://broadcasting.ru/articles2/Mashina/vspominaya-intervidenie/>.

“Россия нашла замену «Евровидению»”, Dni.ru, 21 V 2014, at <https://dni.ru/showbiz/2014/5/21/270892.html>.

Решение о вопросах Межгосударственной телерадиокомпании (22 января 1993 г.), at <http://cis.minsk.by/reestr/ru/index.html\#reestr/view/text?doc=181>.

Соглашение о международно-правовых гарантиях беспрепятственного и независимого осуществления деятельности Межгосударственной телерадиокомпании «Мир» (24 декабря 1993 2.), at <http://cis.minsk.by/reestr/ru/index.html\#reestr/view/text?doc=282>.

Соглашение о создании Межгосударственной телерадиокомпании (9 октября 1992 г.), at <http://cis.minsk.by/reestr/ru/index.html\#reestr/view/text?doc=155>.

Сурма И.В., “ЕАиное информационное пространство СНГ: 20 мет спустя”, Вопросы безопасности, 5 (2015), https://www.doi.org/10.7256/2409-7543.2015.5.17473.

Vitaliy TERESHCHUK, Ph.D. - researcher (Sc.D. candidate) at the International Relations and Foreign Policy department, Petro Mohyla Black Sea State University, Mykolaiv, Ukraine. He specializes in international communications issues. Within this field international and regional information relations, and strategic communications as a tool of foreign policy are of special interest to him. His recent publications are devoted to political issues of emerging, developing and functioning of regional media systems. 